\title{
LIETUVOS GYVENTOJŲ POŽIŪRIS İ MAISTO ŽENKLINIMĄ
}

\author{
Rimantas Stukas $^{1}$, Rokas Arlauskas ${ }^{1}$, Valerij Dobrovolskij ${ }^{1}$, Donatas Austys ${ }^{1}$, \\ Birutė Strukčinskienė², Sigitas Griškonis ${ }^{3,2}$ \\ ${ }^{1}$ Vilniaus universiteto Medicinos fakulteto Sveikatos moksly instituto Visuomenés sveikatos katedra, \\ ${ }^{2}$ Klaipédos universiteto Sveikatos mokslu fakultetas, ${ }^{3}$ Klaipèdos universitetine ligoniné
}

Raktažodžiai: mityba, maisto ženklinimas.

\section{Santrauka}

Maisto ženklinimas vartotojui gali suteikti daug informacijos apie produktą, tik svarbu tą informaciją perskaityti ir teisingai suprasti. Tuomet maisto produkto pasirinkimas bus teisingas, o mityba sveikesnè ir visavertiškesnè.

Tyrimo tikslas - nustatyti, koks Lietuvos gyventoju požiūris ị maisto etiketėse pateikiamą informaciją.

Tyrimo metodika. Tyrimas atliktas 2019 metais visoje Lietuvos teritorijoje. Tikslinè grupe - šalies gyventojai nuo 18 iki 75 metų amžiaus. Per tyrimą taikyta apklausa raštu, apklausti 1008 respondentai. Atliekant tyrimą, naudotas daugiapakopés stratifikuotos tikimybinès atrankos metodas. Duomenų analizè atlikta SPSS/PC programine įranga. Duomenys laikomi statistiškai reikšmingais, kai $p<0,05$.

Rezultatai. Etiketèje pateikiamą produkto sudètị visuomet skaito 26 proc. gyventojų. 38 proc. tai daro kartais, 21 proc. - pavieniais atvejais, 15 proc. - niekada. Renkantis maisto produktus, etikečių informacijos visiškai neskaito 21,1 proc. vyrų ir 8,8 proc. moterų, o dažnai skaito 33,6 proc. moterų ir 17,5 proc. vyrų. Maisto produktų sudètimi etiketèse dažniausiai nesidomi $56 \mathrm{~m}$. amžiaus ir vyresni respondentai $(19,8$ proc.). Nustatyta, kad 36,3 proc. gyventojų, turinčių aukštaji išsilavinimą, dažnai skaito produktų sudètị. Dažnai skaito ir didesnes pajamas gaunantys asmenys. Maisto produktų ženklinimo informacijos visiškai neskaito 16,3 proc. nevedusiujų / netekejjusiųu ir 13 proc. gyvenančiųjų šeimoje. Produktų sudèties neskaito daugiau kaimo $(20,4$ proc.) nei miesto ir rajono centrų gyventojų.

Išvados. Tyrimas atskleidè, kad maisto produktų sudedamosiomis dalimis daugelis gyventojų nesidomi, taigi renkantis maisto produktus jų galimas povei- kis sveikatai Lietuvos gyventojams nèra prioritetas. Todèl svarbu ir prasminga tai, kad direktyviniuose Lietuvos Respublikos dokumentuose kalbama apie sveikos mitybos mokymą, o Lietuvos Respublikos Seimo nutarimu 2019 m. priimtose „Sveikatos tausojimo ir stiprinimo politikos gairèse“" numatyta skatinti sveiką ir subalansuotą mitybą bei nurodytos būtinos veiklos, kurios yra savalaikès ir pagrịstos. Būtina užtikrinti išsamų ir visiems suprantamą informacijos apie maisto sudètị ir vertę pateikimą, naudojant maisto ženklinimą.

Ivadas

Lietuvos Respublikos Seimas 2019 m. liepos 9 d. nutarimu Nr. XIII-2304 patvirtino Sveikatos tausojimo ir stiprinimo politikos gaires, kurių trečiajame skyriuje „Sveikos, subalansuotos mitybos skatinimas" nurodoma, jog sveikatai palankių maisto produktų ir sveikos gyvensenos pasirinkimas sumažina ịvairių ligų riziką bei pagerina bendrą visuomenès sveikatos lygị. Pažymima, kad sveika, subalansuota mityba, ekologiškas maistas dar nèra tapę visuotine vartojimo kultūros dalimi, todèl, skatinant rinktis sveiką ir subalansuotą mitybą, būtina aktyviau šviesti gyventojus ir maisto gamintojus apie sveikos, subalansuotos mitybos naudą žmogaus organizmui ir visuomenei. Svarbu plačiau taikyti socialinę reklamą, kitas sveikos mitybos propagavimo priemones, formuoti bendrą poziciją dèl tam tikrų maisto produktų naudos sveikatai. Privaloma užtikrinti išsamų ir visiems suprantamą informacijos apie maisto sudètį ir vertę pateikimą bei stiprinti vartotojų teisių apsaugą šioje srityje. Reikia atnaujinti ir tobulinti maitinimo paslaugų organizavimą švietimo, gydymo, globos ir kitose ịstaigose, ị tai įtraukiant kvalifikuotus maisto technologus, sveikos mitybos specialistus ir kitus suinteresuotus asmenis. Būtina įtraukti žiniasklaidą į visuomenès mokymus apie sveiką, subalansuotą mitybą, aktyviau populiarinti gyventojų, ypač vaikų, sveikatai palankių produktų pasirinkimą, šviesti Lietuvos gyventojus [1]. 
Sveikos mitybos klausimai paliečiami ir daugelyje kitų svarbių sveikatos politikos dokumentų [2,3]. Lietuva, orientuodamasi i Europos naujosios sveikatos politikos dokumentą „Sveikata 2020“, parenge Lietuvos sveikatos 2014-2025 m. strategiją. Ji sudaryta, atsižvelgiant ne tik ị minètą Europos sveikatos politikos dokumentą, bet ir į Lietuvos pažangos strategijos „Lietuva 2030“, patvirtintos Lietuvos Respublikos Seimo 2012-05-15 nutarimu Nr. XI-2015, 2014-2020 metu Nacionalinès pažangos programos, patvirtintos Lietuvos Respublikos Vyriausybès 2012-11-28 nutarimu Nr. 1482, nuostatas. Strategija patvirtinta Lietuvos Respublikos Seimo 2014 m. birželio 26 d. nutarimu Nr. XII-964, įregistruotu Teisès aktų registre (TAR) 2014-07-01 (identifikacijos kodas 2014-09403). Kad 2025 m. būtų pasiektas pagrindinis Lietuvos sveikatos strategijoje numatytas tikslas - sveikesnis ir ilgesnis šalies gyventojų gyvenimas, geresnè jų sveikata ir mažesni sveikatos netolygumai - išsikelti keturi strateginiai tikslai, iš kurių trečiasis numato ir sveikos mitybos ịpročių skatinimą. Kalbant apie visas su sveika mityba susijusias ir pabrezžiamas veiklas, pagrịstai nurodoma, jog būtina užtikrinti išsamų ir visiems suprantamą informacijos apie maisto sudètị ir vertę pateikimą. Labai svarbu, kad gyventojai, rinkdamiesi maisto produktus, skaitytų ir suprastų maisto produktų etikečiu informaciją. Tai neabejotinai reikšmingai paveiktų žmonių ịpročius, jiems renkantis sveikatai palankesnius maisto produktus, kartu turètų reikšmingos įtakos sveikai mitybai ir sveikatai. Mokslininkai, apibendrinę ilgalaikius tyrimus, irodè, kad sveikata glaudžiai susijusi su socialiniais ir ekonominiais rodikliais [4].

Renkantis maisto produktus, ypač svarbus yra gyventojų sveikatos raštingumo lygis, nes sveikata didžiaja dalimi priklauso nuo mitybos. Deja, kaip rodo $2018 \mathrm{~m}$. Lietuvos gyventojų sveikatos raštingumo tyrimas, tik 60 proc. Lietuvos gyventojų sveikatos raštingumo lygis buvo pakankamas arba puikus, 40 proc. - neadekvatus arba probleminis. Didžiausias gyventojų nepakankamo sveikatos raštingumo lygis buvo konstatuotas ligu prevencijos (36,7 proc.), mažiausias - sveikatos stiprinimo (31,3 proc.) srityse. Mažiausiu sveikatos raštingumo lygiu pasižymi vyresnio amžiaus, žemesnio išsilavinimo asmenys, našliai, pensininkai bei kaimo gyventojai [5].

Sveikatos ir mitybos sąsajos įrodytos ir pagrịstos įvairiais moksliniais tyrimais. Neabejojama, kad žemas sveikatos raštingumas lemia nesveiką mitybą, nesidomejjimą įsigyjamo maisto sudètimi ir verte. Po Lietuvoje atliktų tyrimų nustatyta, jog daugelio darbingo amžiaus gyventojų faktiniai mitybos ịpročiai neatitinka sveikos mitybos rekomendacijų $[6,7,8,9,10,11]$.

Ryšys tarp sveikatos raštingumo ir sveikatos būklès yra gerai dokumentuotas. Nustatytos sąsajos tarp sveikatos raštingumo, prastesnio gebejjimo interpretuoti etiketes bei sveikatos pranešimus ir blogos bendros sveikatos būklès bei didesnio mirtingumo [12].

Maisto produkto etiketeje pateikiama informacija apie produkto sudètį vartotojui gali suteikti labai daug žinių apie produktą, tik svarbu tą informaciją perskaityti ir teisingai suprasti. Tuomet maisto produkto pasirinkimas bus teisingas, o mityba - sveikesnè ir visavertiškesnè.

Tyrimo tikslas - nustatyti, koks Lietuvos gyventojų požiūris ị maisto etiketèse pateikiamą informaciją.

\section{Tyrimo metodika}

Tyrimas atliktas 2019 metais visoje Lietuvos teritorijoje, taikyta apklausa raštu. Tikslinė grupe - šalies gyventojai nuo 18 iki 75 metų amžiaus. Atliekant tyrimą, buvo apklausti

1 lentelè. Maisto produktų etiketès skaitymas, priklausomai nuo lyties $(\%)$.

\begin{tabular}{|l|c|c|c|}
\hline \multirow{2}{*}{$\begin{array}{l}\text { Maisto produkto eti- } \\
\text { ketės skaitymas }\end{array}$} & \multicolumn{2}{|c|}{ Lytis } & \multirow{2}{*}{$\begin{array}{c}\text { Visi respon- } \\
\text { dentai }\end{array}$} \\
\cline { 2 - 3 } & Vyrai & Moterys & 26,2 \\
\hline Dažnai & 17,5 & 33,6 & 37,8 \\
\hline Kartais & 37,7 & 37,9 & 21,5 \\
\hline Pavieniais atvejais & 23,7 & 19,7 & 14,5 \\
\hline Neskaito & 21,1 & 8,8 & \\
\hline
\end{tabular}

2 lentelè. Maisto produktų etiketės skaitymas, priklausomai nuo amžiaus (\%).

\begin{tabular}{|l|c|c|c|c|c|c|}
\hline \multirow{2}{*}{$\begin{array}{l}\text { Maisto produkto } \\
\text { etiketės skaitymas }\end{array}$} & \multicolumn{5}{|c|}{ Amžius (metais) } & \multirow{2}{*}{$\begin{array}{c}\text { Visi res- } \\
\text { pondentai }\end{array}$} \\
\cline { 2 - 6 } & $\mathbf{1 8 - 2 5}$ & $\mathbf{2 6 - 3 5}$ & $\mathbf{3 6 - 4 5}$ & $\mathbf{4 6 - 5 5}$ & $\begin{array}{c}\mathbf{5 6} \text { ir } \\
\text { daugiau }\end{array}$ & \\
\hline Dažnai & 14,8 & 27,4 & 24,9 & 31,0 & 27,8 & 26,2 \\
\hline Kartais & 42,2 & 38,9 & 43,3 & 35,8 & 32,3 & 37,8 \\
\hline Pavieniais atvejais & 25,8 & 24,2 & 17,9 & 21,7 & 20,2 & 21,5 \\
\hline Neskaito & 17,2 & 9,5 & 13,9 & 11,5 & 19,8 & 14,5 \\
\hline
\end{tabular}

3 lentelė. Maisto produktų etiketės skaitymas, priklausomai nuo išsilavinimo (\%).

\begin{tabular}{|l|c|c|c|c|}
\hline \multirow{2}{*}{$\begin{array}{l}\text { Maisto produkto eti- } \\
\text { ketės skaitymas }\end{array}$} & $\begin{array}{c}|c| \\
\text { Išsilavinimas }\end{array}$ & \multirow{2}{*}{$\begin{array}{c}\text { Visi res- } \\
\text { nebaigstasis / } \\
\text { aukštasis }\end{array}$} & $\begin{array}{c}\text { Vidurinis / } \\
\text { specialusis } \\
\text { vidurinis }\end{array}$ & $\begin{array}{c}\text { Nebaigtas } \\
\text { vidurinis } \\
\text { pondentai }\end{array}$ \\
\hline Dažnai & 36,3 & 23,4 & 8,7 & 26,2 \\
\hline Kartais & 38,1 & 38,5 & 26,1 & 37,8 \\
\hline Pavieniais atvejais & 15,6 & 23,1 & 32,6 & 21,5 \\
\hline Neskaito & 10,0 & 15,0 & 32,6 & 14,4 \\
\hline
\end{tabular}


1008 respondentai. Taikytas kombinuotas tyrimo metodas: 60 proc. CAPI (angl. Computer Assisted Personal Interview) ir 40 proc. CAWI (angl. Computer Assisted Web Interview). CAPI apklausą atliko profesionalus klausejjas, kuris per pokalbị su respondentu rèmėsi iš anksto parengtais klausimais, o atsakymus fiksavo klausimyne. Per CAWI apklausą respondentui buvo siunčiama nuoroda ị apklausos formą, šią formą respondentas užpildè savarankiškai jam / jai patogiu metu. Nuoroda unikali, t. y. klausimyno negalima užpildyti kelis kartus. Atliekant tyrimą, naudotas daugiapakopès stratifikuotos tikimybinès atrankos metodas. Šis atrankos metodas užtikrina duomenų reprezentatyvumą, t. y. kiekvienas šalies namų ūkis turi vienodas galimybes dalyvauti apklausoje ir atrankine visuma pagal tikslinius kriterijus atitinka generalinę visumą. Tyrimo rezultatai reprezentuoja šalies gyventojų nuo 18 iki 75 metų nuomones ir vertinimus. Duomenų analizė atlikta, naudojantis SPSS/PC programinè įranga. Duomenys laikomi statistiškai reikšmingais, kai $\mathrm{p}<0,05$.

\section{Rezultatai ir jų aptarimas}

Tyrimo rezultatai atskleidè, kad rinkdamiesi maisto produktus etikečių informacijos visiškai neskaito 21,1 proc. vyru ir 8,8 proc. moterų. Maisto produktų sudètis etiketėse kartais skaito 38 proc. gyventojų, o dažnai - 33,6 proc. moterų ir 17,5 proc. vyrų ( 1 lentelè). Taigi maisto produktų sudètis ženkliai labiau rūpi moterims.

Dažnai etiketes skaito 46-55 metų amžiaus respondentai (31 proc.), kartais -36-45 metų amžiaus respondentai (43,3 proc.). Maisto produktų sudèties, pateikiamos etiketėse, dažniausiai neskaito $56 \mathrm{~m}$. ir vyresni respondentai, kas sudaro 19,8 proc. (2 lentelè).

Kuo aukštesnis išsilavinimas, tuo didesnè dalis respondentų skaito etiketèje pateikiamą maisto produktų sudedamujjų dalių sąrašą. 36,3 proc. gyventojų, turinčių aukštajj išsilavinimą, dažnai skaito produktų sudètị (3 lentelè). Dažnai maisto produktų sudètimi domisi ir didesnes pajamas gaunantys asmenys.

Maisto produktų ženklinimo informacijos visiškai neskaito 16,3 proc. nevedusiujjų / netekejjusiujų ir 13,0 proc. gyvenančiųjų šeimoje. Produktų sudèties neskaito daugiau kaimo (20,4 proc.) nei miesto ir rajono centruose gyvenančių asmenų. Tai, kad dažnai skaito maisto produktų sudètį, nurode daugiau moteru, taip pat daugiau $45-55 \mathrm{~m}$. amžiaus, aukštesnio išsilavinimo bei didesnes pajamas gaunančių atstovų. Tai, kad niekada to nedaro, teigè daugiau vyrų, jauniausio ir vyriausio amžiaus respondentų, daugiau žemesnio išsilavinimo bei mažiausias pajamas gaunančių atstovų.

Tyrimas atskleidè, kad dažnai produktų sudètį parduotuvèse skaito 26 proc. gyventojų, 38 proc. tai daro kartais, 21 proc.- pavieniais atvejais, 15 proc. - niekada. Tyrimo rezultatai parodè, kad būtina šviesti Lietuvos gyventojus, atkreipiant dèmesi i mitybos ir sveikatos sąsajas, mokyti juos sveikos gyvensenos pagrindų, privalu siekti aukštesnio sveikatos raštingumo lygio, formuoti tinkamą požiūrị i mitybos įpročius. Ypač svarbu išaiškinti visuomenei maisto produktų ženklinimo svarbą, atkreipti jos demesį ị tai, kad pasirinkti tinkamus maisto produktus gali padeti informacija, esanti ant maisto produktų, maisto gaminių bei maisto prekių pakuotès. Šios pakuotès etiketėse nurodyta maisto produktų sudètis bei jų maistinè ir energinè vertè padètų pasirinkti sveikatai palankesnį maistą. Tai igalintų gyventojus sveikai maitintis, o kartu prisidètų ir prie jų sveikatos stiprinimo.

\section{Išvados}

Tyrimas atskleidè, kad maisto produktų sudedamosiomis dalimis daugelis gyventojų nesidomi, iš jų daugiausia vyrai, jauniausio ir vyriausio amžiaus, žemesnio išsilavinimo, mažiausias pajamas gaunantys respondentai. Taigi renkantis maisto produktus, Lietuvos gyventojams jų galimas poveikis sveikatai nėra prioritetas. Todèl itin svarbu, kad direktyviniuose Lietuvos Respublikos dokumentuose, kuriuose kalbama apie sveikos mitybos mokymą, taip pat Lietuvos Respublikos Seimo nutarimu 2019 m. priimtose Sveikatos tausojimo ir stiprinimo politikos gairèse, numatyta skatinti sveiką ir subalansuotą mitybą bei nurodytos būtinos veiklos, kurios yra savalaikès ir pagrịstos. Būtina užtikrinti išsamios ir visiems suprantamos informacijos apie maisto sudètį ir vertę pateikimą, naudojant maisto ženklinimą.

\section{Literatūra}

1. Lietuvos Respublikos Seimo nutarimas "Dèl sveikatos tausojimo ir stiprinimo politikos gairių patvirtinimo". $2019 \mathrm{~m}$. liepos $9 \mathrm{~d}$. Nr. XIII-2304. Vilnius.

2. Health 2020: a European policy framework and strategy for the 21 st century. WHO Regional Office for Europe (Copenhagen). 2013. Prieiga per internetą: http://www.euro.who.int/_data/ assets/pdf file/0011/199532/Health2020-Long.pdf?ua $=1$.

3. Regions for health network. WHO Regional Office for Europe (Copenhagen). 2012. Prieiga per internetą: http://www.euro. who.int/en/about-us/networks/regions-for-health-network-rhn/ about-rhn.

4. Wilkinson R, Marmot M (eds). Social determinants of health: the solid facts. WHO Regional Office for Europe (Copenhagen). 2003.

5. Javtokas Z., Sabaliauskas R., Žagminas K., Umbrasaitė J. Suaugusių Lietuvos gyventojų sveikatos raštingumas. Visuomenès sveikata, 2013;4(63):38-46.

6. Barzda A., Bartkevičiūtė R., Baltušytė I., Stukas R., Bartkevičiūte S. Suaugusių ir pagyvenusių Lietuvos gyventojų faktinès mitybos ir mitybos ịpročių tyrimas. Visuomenès sveikata, 2016;1(72):85-94. 
7. Mimgaudytė L., Rapolienė L. Suaugusių žmonių mitybos įpročių vertinimas remiantis sveikos gyvensenos principais. Sveikatos mokslai, 2015;25(6):22-28.

https://doi.org/10.5200/sm-hs.2015.111

8. Juozulynas A., Jurgelėnas A., Venalis A., Sąlyga J., Stukas R., Dobrovolskij V. Sveikatos integralumas ir valdymas. Monografija. Druka (Klaipèda). 2014.

9. Žandaras Ž., Stukas R. Sveikatai nepalankių maisto produktų ir gérimų vartojimo paplitimas tarp Vilniaus universiteto studentų. Visuomenès sveikata, 2015;2(69):36-40.

10. Stukas R., Dobrovolskij V. Kofeino turinčių produktų vartojimas Lietuvoje. Visuomenės sveikata, 2014;priedas Nr. 1:40-45.

11. Dobrovolskij V., Stukas R. Lietuvos gyventojų mitybos įpročių ir cholesterolio koncentracijos kraujyje sąsajos. Visuomenès sveikata, 2014;priedas Nr. 1:64-69.

12. Nielsen-Bohlman L, Panzer AM, Kindig DA (eds). Health literacy: a prescription to end confusion. Institute of Medicine (US), Committee on Health Literacy. National Academies Press (US) (Washington, DC). 2004.

\section{ATTITUDES OF LITHUANIAN POPULATION TOWARDS FOOD LABELLING}

R.Stukas, R.Arlauskas, V.Dobrovolskij, D.Austys, B.Strukčinskienė, S.Griškonis

Key words: nutrition, food labelling.

Summary

Food labelling can provide relevant information to the consumers about the particular products they are going to buy, but the first step is paying attention to this kind of information and perceiving it properly. This perception is crucial making a right choice of food as well as choosing a healthier and more nutritious diet. The aim of this research is to identify the attitudes of Lithuanian population towards food labelling.

Methods. The survey was conducted in 2019 in the whole territory of Lithuania. The target group was the population from 18 to 75 years old. In the research, a written survey was applied and
1,008 respondents were interviewed. The method of multilevel stratified probability sampling was chosen to perform the study. Data analysis was carried out using SPSS/PC software. Data were considered statistically significant if $\mathrm{p}<0.05$.

Results. The food labels are read by $26 \%$ of Lithuanian population, $38 \%$ of Lithuanian population sometimes read the nutrition facts, $21 \%$ of them rarely do it, and $15 \%$ - never seek for such kind of information (21.1\% men and 8.8\% women). Nutrition information is often an object of interest to $33.6 \%$ women and $17.5 \%$ men. Information provided in food labels are mostly not read by individuals aged 56 years and older (19.8\%). Persons who have acquired a higher education, i.e. $36.3 \%$ of population, often read the composition of products. High-income earners also read the nutrition facts often. Furthermore, the research showed that $16.3 \%$ of unmarried and $13.0 \%$ of married respondents are not interested in food labels at all. More people living in rural areas (20.4\%) than those who reside in urban areas do not read information about the food composition.

Conclusions. The study revealed that the majority of respondents are not interested in the ingredients of food. Therefore, the residents of Lithuania do not think that the nutrition impact on their health is a priority choosing the food products. According to Lithuanian directive documents for teaching about healthy nutrition, as well as The Guidelines concerning the Policy of Health Maintenance and Its Improvement (confirmed by Parliament of the Republic of Lithuania in 2019), the promotion of healthy and balanced nutrition is already planned and the necessary timely as well as evidence-based activities are specified. In previously mentioned documents and the conclusions of this paper, consumer need for an introduction of understandable and detailed information on the composition and value of food products through the food labelling is emphasized.

Correspondence to: rimantas.stukas@mf.vu.lt

Gauta 2019-09-17 